\title{
CORRECTION
}

Yongbin Zhang $\mathbb{D}$

\section{Correction to: Multiscale mixed hydrodynamics in line contacts}

Published online: 31 December 2021

(C) Springer-Verlag GmbH Germany, part of Springer Nature 2021

Correction to: Continuum Mech. Thermodyn. https://doi.org/10.1007/s00161-021-01068-2

In this article, ref. 22 was incorrect and should have been 'Zhang, Y.B.: Modeling of molecularly thin film elastohydrodynamic lubrication. J. Balkan Trib. Assoc. 10, 394-421 (2004)'.

Publisher's Note Springer Nature remains neutral with regard to jurisdictional claims in published maps and institutional affiliations.

The original article can be found online at https://doi.org/10.1007/s00161-021-01068-2.

Y. Zhang $(\varangle)$

College of Mechanical Engineering, Changzhou University, Changzhou, Jiangsu Province, China

E-mail: engmech1@ sina.com 